\author{
Near East University Online Journal of Education (NEUJE) \\ Received: March 10, 2019 Revised: April 29, 2019 Accepted: June 03, 2019
}

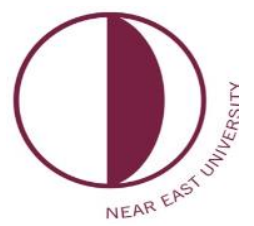

\title{
AN EVALUATION OF THE EFFECTIVENESS OF THE CYPRUS AND CYPRUS TURKISH HISTORY COURSE CURRICULUM OBJECTIVES IN SCHOOL PRACTICES
}

\author{
İpek Danju ${ }^{{ }^{*}}$ \\ ${ }^{1}$ Division of Curriculum and Instruction, Ataturk Education Faculty, Near East University, North Cyprus, Via \\ Mersin 10, Turkey, ipek.danju@ @eu.edu.tr \\ Correspondence: ipek.danju@ neu.edu.tr ; Tel.: ++90(392) 2236464
}

\begin{abstract}
The aim of this study is to determine the effectiveness of the Cyprus and Cyprus Turkish History course curriculum's objectiveness and the teachers' implementation of the curriculum in schools. The research was conducted using a qualitative research approach and a descriptive research model. In this study, the qualitative research is structured using the case study pattern The researcher prepared semi-structured interview form to reveal the teachers' views. Content analysis method was applied through using Nvivo 10 software in the analysis of qualitative data. The analysis of the survey data was conducted by encoding the results, as well as dividing and categorizing the teacher's feedback and opinions; furthermore, direct opinions have also been noted. According to the findings, not only is there a disparity between the application of the program and its original objectives, but the effectiveness of the curriculum is also questioned.
\end{abstract}

Keywords: education, curriculum, Cyprus and Cyprus Turkish history, qualitative

\section{Introduction}

The present study provides detailed information regarding the curriculum's applicability, affordability, functionality, flexibility - individual differences between students should be monitored; the technological developments should be adopted - and the social values that should be goal-oriented should also be protected and transferred to the new generations in the most effective manner. For this reason, the specialists who develop curricula systematically, the authorities who responsible for educational policies, the teachers who implement the curricula and the students who are generally the learners, should benefit accordingly. Therefore, curricula should be designed with contemporary approaches and should represent current issues. In curricula, learning situations should be planned according to specific goals and testing should be effective in evaluating specified target behavior. Today, for the development of technology and in order to provide students with modern skills, contemporary education approaches should be implemented at every level of educational institutions.

Educating individuals who understand the historical, political, societal and cultural phenomena of the globalized world and providing them with the necessary knowledge, skills, attitude and behavior that will prepare them to meet the needs of modern society are among the aims of the Cyprus and Cyprus Turkish History curriculum, which is the primary focus of this study (MEB, 2016). The curriculum of the Cyprus and Cyprus Turkish History course is 
student-centered insights are prominent. General approach of the program is reconstructivisim.

Sakaoglu (2008) claimed that history curricula should be designed according to certain harmonization and coordination requirements. Additionally, he stated that an appropriately selected course book should be directly related to a teacher's area of expertise and occupational knowledge. The history curricula that are in use should be evaluated in terms of their objectives, content, learning-teaching activities, assessment and evaluation. Evaluating curricula in terms of the knowledge and skills gained can be interpreted as converting behavior into targeted objectives. The content of the curricula should be formulated in a manner that answers the question 'what shall we teach?', when the curricula is evaluated in terms of its content. In other words, the content should correspond to the targeted behavior. Evaluating curricula in terms of learning-teaching activities implies that learning situations should be organized in a manner that will assist students to acquire the targeted behavior. Demirel (2006) believed that learningteaching processes have the goal of evaluating the efficiency of the learning experiences of students during the learning process. At the same time, the efficiency of the instructor's teaching experiences is also evaluated. Measuring and evaluating curricula, which are the final stage of educational activities, should involve evaluating students as well as the teaching activities.

The article state of the literature as history education is important for international relations and contributes to the resolution of interstate disputes in a peaceful manner. Also, analysis of history course curriculums meets the requirements for further studies and helps to update the current curriculum.

The contribution of this paper to the literature is systematic curriculum evaluation which determine the effectiveness of the Cyprus and Cyprus Turkish History course curriculum's objectiveness and the teachers' implementation of the curriculum in schools.

The aim of this study is to provide recommendations with the intention of enhancing the existing curriculum of the Cyprus and Cyprus Turkish History course that is taught in school year 6-7-8-9-10 in the Turkish Republic of Northern Cyprus by evaluating the opinions of the teachers who implement the relevant curriculum. The data that were collected through the curriculum evaluation studies could provide the curriculum designers and teachers with valuable feedback about the efficiency of the existing curriculum of the Cyprus and Cyprus Turkish History course. Thus, beneficial information regarding the direction the existing curriculum should take and how it should be developed based on the data that were collected at the end of the curriculum evaluation can be provided to the stakeholders (Ministry of Education, Turkish Education Board, Educational Administration, teachers and students). Curriculum evaluation studies, in general, should be scientific and systematic. It is crucial that tangible benefits are drawn from the results of the evaluation studies. In other words, the preparation of educational reforms should be fundamentally supported by curriculum evaluation studies.

Another importance of this study is that, by gauging the opinions of the teachers who implement the curriculum of the Cyprus and Cyprus Turkish History course, this will provide valuable insights into the level of efficiency of the curriculum as well as whether the targets have been achieved. Furthermore, evaluating one of the components of the curriculum that is objectives and contributing to the scientific basis of education, will provide valuable knowledge to the teachers, who are curriculum implementers, and to those who develop curricula, by specifying the parts that are required to be rewritten for the improvement of the 
curriculum. Within the scope of the study, the research on the importance of education, the necessity of history education and the evaluation of the efficiency of the implementation of the curriculum of the Cyprus and Cyprus Turkish History course are all included. Additionally, research on the importance of the curriculum evaluation is accommodated.

The aim of this study is to provide curriculum development specialists and teachers with feedback regarding the efficiency of the present Cyprus and Cyprus Turkish History course as a result of the curriculum evaluation studies. Thus, a final decision will be taken in order to determine whether either the present curriculum will be continued, certain insufficient elements are reconsider or if a completely new curriculum should be developed. Therefore, in accordance with this purpose, the following questions have been prepared:

What are the opinions of the history teachers regarding the Cyprus and Cyprus Turkish History course that is taught in school year 6th, 7th, 8th, 9th, and 10th in terms of the objectives of the curriculum?

\section{Literature Review}

\subsection{Empirical Studies, Studies on Curriculum Evaluation in Education}

The curriculum is one of the most important aspects of the educational system and is also a reflection of the political, economic, cultural and social structure of the country in which the the curriculum is developed. Varis (1998) expressed that the main aim of a curriculum is to provide a sufficient level of knowledge and skills to students in order to prepare them for the developments of the modern age. This is why the curricula produce learning and teaching activities that guide students to achieve the required changes in their behaviors. Therefore, educating students who are qualified with contemporary, technological and global characteristics and who are are entrepreneurial, creative, innovative, and can easily adapt to new developments is significantly dependent on the quality and efficiency of the curricula. In this context, the educational policies and philosophies of countries are directly proportionating to each individual who is educated in a manner that will enable to be effective within the contemporary system in the society (Kose, 2011). In other words, preparing individuals who are highly-educated global citizens and encouraging them to acquire a level of professionalism in their chosen careers through an efficient, qualified, practical and successful education system and curriculum are among the principal targets of educational policies. Therefore, the actions of accomplishing these targets and conveying them to the individuals are dependent on the quality and success of the curricula. The knowledge, skills and behavior that individuals are required to acquire are integrated into certain courses and subjects. Therefore, one could conclude that educational curricula cover both curricula and extra-curricular activities.

The reality, practicality, productivity and efficiency of education can only be maintained by curricula that are planned systematically (Demirel, 1996; Erden, 1995; Kucukahmet, 1995). Therefore, it can be said that curricula that are designed systematically by using scientific techniques are a link between society and individuals. This acts as a bridge that conveys the criteria to individuals. Furthermore, it is one of the basic determinants of education and is a set of coordinated learning experiences (Akyuz, 2014; Tezcan, 1985; Wiles \& Bondi, 1993).

Curriculum development and curriculum evaluation form a systematic circle and these two elements complete each other. They are reliant on each other and their objective is to meet the needs at the highest level (Erturk, 2013). The origins of curriculum evaluation studies can be traced back to the 1930s. Between 1932 and 1940, Tyler pursued in-depth curriculum studies 
over a period of eight years. Tyler (1975) claimed that efficient and high-quality education could only be achieved by transforming instructional objectives into behaviors. It is also significant to highlight that changing instructional objectives into behaviors successfully is completely dependent on the success of the curriculum in use. Tyler (1975) stressed the importance as well as the necessity of curriculum evaluation. Fortunately, by the beginning of the 21 st century, curriculum evaluation studies began to become more systematic.

Oliva (1988) claimed that evaluation is conducted for two reasons; one of which is to evaluate the education and the other one is to evaluate the curriculum. Evaluation of the instruction is only possible by taking into account the students' results, the field and pedagogic knowledge of instructors as well as the efficiency of the strategies, methods, techniques and equipment that are used in the teaching period. Curriculum evaluation, however, is a more comprehensive process that encompasses curriculum evaluation studies in its entirety. Saylor, Sanders and Lewis (1981) claimed that evaluation could be conducted in both a directional and purposive manner. Worthern and Sanders (1973), on the other hand, believed that evaluation is helpful for acquiring information about the value and usefulness of the curricula, whether they are beneficial or not and to what extent they are appropriate for the purpose. Hopkins (1989) expressed that evaluation is a state of determining something systematically. Likewise, Brown (1989) defined evaluation as a process where detailed and updated information is collected and analyzed systematically and then used to support the curriculum, to assist with improving the weak points, to reorganize certain points and to determine the efficiency of the curriculum.

In order to establish the aim of the evaluation study, the expectations of the institution that initiates the evaluation and to what extent the needs of the society are met are all taken into account, which explains why it is believed that awareness would be created as a result. Thus, the conclusions drawn regarding the curriculum should be useful for improving education, achieving its aims and should be functional and beneficial. In fact, it could be said that evaluation is a highly beneficial mechanism and is also the stage where decisions can be made to assess whether a curriculum is beneficial or not.

Additionally, the required information is obtained from the stakeholders who directly implement the curriculum during the evaluation process of the curricula. Parents, directors, curriculum development specialists, field experts, ministry staff and examiners are among these stakeholders. Varis (1997) believed that, in order to decide whether a curriculum is effective or not, the general and specific targets of the curriculum development process should first be examined. Then, it is investigated whether these aims and targets have been achieved and finally, a set of data collection instruments are developed according to the characteristics of both the students and teachers. In terms of this perspective, Erden (1998) claimed that reliable information about the efficiency of the curriculum could only be obtained by developing the data collection instruments in an appropriate manner.

Demirel (2006) claimed that conducting curricula evaluation studies provides the specialists with certain ideas about the success and efficiency of the curriculum and also offers an opportunity for the curriculum development specialists to either continue with the current curriculum, complete any missing aspects or even reconsider entirely the curriculum that is developed and is being implemented. For this reason, the curriculum development studies and curriculum evaluation studies should never be managed separately. as these two concepts are interlinked. By incorporating the results of the curriculum evaluation studies, certain improvements are made to increase the efficiency of the curricula that are developed after intensive, scientific, and systematic studies (Fitzpatrick, Sanders \& Worthen, 2004; Varis 
1988). Evaluating curricula covers the stages of curricula development - identifying needs, targets, content, learning-teaching process and evaluation. Whether the curriculum that is developed systematically is efficient and productive or not can only be determined through the evaluation process (Dogan, 1997; Erturk, 2013; Marsh \& Willis, 2007).

The scope of this study includes the evaluation of the curriculum of the Cyprus and Cyprus Turkish History course and identifying the missing aspects, where appropriate, and completing them according to the curriculum evaluation results. Therefore, after a detailed literature review, it was decided that it would be appropriate to evaluate the curriculum of the Cyprus and Cyprus Turkish History course that is taught at school year 6-7-8-9-10. This evaluation presents both negative and positive information about the curriculum for the people who are responsible for making decisions about the curriculum.

\section{Method}

\subsection{Research Model}

In this study, the qualitative research is structured using the case study pattern. This study is descriptive in the form of a survey model and focuses on evaluating the curriculum of the Cyprus and Cyprus Turkish History course. From NVivo analysis it is found that data reduction (Batdi, 2014; Kocoglu \& Aydin, 2017). The study has the purpose of collecting data in order to identify various characteristics of the curriculum by analyzing the opinions of the teachers who teach the Cyprus and Cyprus Turkish History course.

\subsection{Population and Sample}

The population of the study was composed of the teachers who teach the Cyprus and Cyprus Turkish History course to the $6^{\text {th }}, 7^{\text {th }}, 8^{\text {th }}, 9^{\text {th }}$, and $10^{\text {th }}$ grade students. For the qualitative dimension of the study, the opinions of the 12 history teachers who implement the curriculum of the Cyprus and Cyprus Turkish History course to the $6^{\text {th }}, 7^{\text {th }}, 8^{\text {th }}, 9^{\text {th }}$, and $10^{\text {th }}$ grade students in the Northern Cyprus of Turkish Republic were taken on a voluntary basis. The sample of the study, however, was composed of 12 teachers who work for the secondary school institutions in Omorfo, Lefka, Karpasia, Famagusta, Trikomo and Kyrenia.

\subsection{Data Collection Instruments}

Semi-structured interview form was used in this study. The interview form that was prepared for the history teachers of the secondary school institutions of the Turkish Republic of Northern Cyprus. Interview form were developed by the researcher after the relevant literature was reviewed. Prior to conducting the interview with the teachers, the interview form was sent to two history education, one qualitative research, and five educational sciences specialists to verify the content validity. The form was finalized after conducting a pilot study to determine the accuracy of the report and then the interviews commenced. 


\subsection{Semi-Structured Interview Form}

The researcher developed the teacher's interview form in order to evaluate the curriculum in terms of the objectives. The interview question is the effectiveness of the Cyprus and Cyprus Turkish History course curriculum objectives in school practices?

\subsection{Data Collection Process}

For the interviews with the 12 history teachers who teach the Cyprus and Cyprus Turkish History course, permission was obtained either via telephone or by making an appointment. Particularly attention was given to the locations where the teacher interviews occurred to ensure that they were sufficiently quiet that clear recordings could be made. The researcher designed all the questions on the semi-structured interview form. The interview had a duration of between 40 and 50 minutes and were recorded by the researcher.

\subsection{Data Analysis}

NVivo 10 package program was used for the analysis of qualitative data. Programs are tools that accelerate data analysis and simplify the process by processes such as data storage, encoding, recall, merging and visualization. However, the researcher applies the analysis process. The qualitative data analysis steps of the research in this direction are as follows:

The interviews with teachers were recorded. These records were transferred to the computer and then listened by the researcher and transcribed by using Microsoft Office program. These documents were uploaded to the Nvivo10 program and a project named "student negotiations" was created. The crude data obtained from the interviews was cleared. Then the data was coded. During the coding process, significant parts of the obtained were selected and the conceptual meaning of each part was found. While coding the data, the induction approach was used and the codes were formed as free codes. Free codes were put together according to their characteristics and the themes were created. The appropriateness of the coding in the study was reviewed by two experts (peer review). 37 of the 40 codes created by the researcher were accepted by the experts. It was determined that the researcher and the experts $92 \%$ reached a consensus on the codes by using the reconciliation percentage formula Reconciliation Percentage $=\mathrm{Na}$ Consensus $/[\mathrm{Na}$ (Consensus Unit $+\mathrm{Nd}$ Disagreement) $\mathrm{x} 100]$ introduced by Miles and Huberman (1994). A value, which is over $80 \%$, shows that the research is reliable (Miles and Huberman, 1994). The codes, which were left out, were replaced by the new ones offered by researcher and so the codes were finalized. Then the obtained data were digitized and quantified. The frequency of repetition of the codes and themes obtained within the scope of the research were calculated and presented in tabular form. A detailed and direct citation was given in terms of the validity and reliability of the results obtained. At this stage, the names of the teachers were coded as Teacher 1 , Teacher $2 \ldots$ because of the ethics of the research.

For the qualitative data analysis, descriptive analysis techniques were used to analyses the opinions of the teachers regarding the evaluation of the Cyprus and Cyprus Turkish History curriculum within the scope of this study. The content analysis, which is one of the qualitative data analyses, was used to conduct in-depth analysis over the data that were obtained through the interviews. The reason for using content analysis was due to the themes and codes that emerged from the interviews. The opinions of the teachers were directly conveyed through the descriptive analysis. Tavsancil and Aslan (2001) claimed that qualitative data are rendered more meaningful after they are analyzed and concretized with the aid of codes and categories. 
All the data were checked many times and some patterns emerged and then these patterns were coded under node option. All the nodes were in the tree node format hierarchically. But, after the data analysis developed, the relationships between the codes became easier to see and the researcher started grouping them using tree codes and major codes were grouped as the aim of the research goals. NVivo helps tremendously from conceptualization and coding of data to an entire research report saving time and energy of researchers (Gibbs, 2002; Richard, 2002).

During the analysis, the data were coded and categorized. A number of direct quotations were used from the teachers' opinions. The interview samples that were formed for the evaluation of the Cyprus and Cyprus Turkish History curriculum were carefully read several times and a code list was formed accordingly. The data are considerably significant while forming the code list. After the coding, the themes were formed. The code list and the themes were then sent to the qualitative research experts to be reviewed and finalized.

The codes and the themes that were obtained through the content analysis of the interviews are presented with direct quotations to facilitate the comprehension of the readers. The quotations are presented with quotation marks and certain abbreviations used to represent the teachers. This enabled the teachers to be considered anonymously, regardless of their gender, age, etc. The teachers are abbreviated as Teacher 1, Teacher 2, and Teacher 3.

\section{Results and Discussions}

\subsection{Findings and Comments Obtained Through the Teacher Interview Form}

A database has been created in accordance with the topics obtained related to the targets of the program. Considering the opinions of the teachers who are the implementers of the program, the aim is to determine the objectives aimed to be delivered to students, in terms of their knowledge, skills, value of the product, the environment within which the program is conducted, the existing conditions of the program, and the needs and requirements that may not have been satisfied, if appropriate.

The qualitative data derived from the teachers' opinions on Cyprus and Cyprus Turkish History Teaching Program are classified in accordance with their themes and presented in Table 1. The opinions of teachers on Cyprus and Cyprus Turkish History and the themes created in accordance with their opinions are presented as two themes, as follows: "Cognitive high level thinking skills and status of achieving the objectives" and "Thinking skills related to teaching history". The opinions of teachers for the first theme are classified on the basis of seven different codes, and the opinions of teachers regarding the second theme are classified on the basis of five different codes. 
Table 1. Opinions of history teachers on the program objectives of the Cyprus and Cyprus Turkish History course taught in the year 6-7-8-9-10 classes at schools

\begin{tabular}{|c|c|}
\hline Themes & Codes \\
\hline \multirow{7}{*}{$\begin{array}{c}\text { Cognitive High-Level Thinking Skills and } \\
\text { Status of Achieving Objectives }\end{array}$} & Problem solving skills \\
\hline & Using information and technology \\
\hline & Research - investigation skills \\
\hline & Critical thinking skills \\
\hline & Creative thinking skills \\
\hline & Communication skills \\
\hline & $\begin{array}{l}\text { Skills that can be used to fulfill the needs and } \\
\text { requirements of the continuously changing } \\
\text { needs of the } 21^{\text {st }} \text { Century. }\end{array}$ \\
\hline \multirow{5}{*}{ Thinking Skills } & $\begin{array}{l}\text { The skills to think historically, analyze and } \\
\text { interpret }\end{array}$ \\
\hline & $\begin{array}{l}\text { In a globalized world, the ability to perceive } \\
\text { political, social, economic and cultural events }\end{array}$ \\
\hline & Introduces chronological thinking skills \\
\hline & Research based on the investigation of history \\
\hline & $\begin{array}{l}\text { Universal values, giving particular importance } \\
\text { to national values }\end{array}$ \\
\hline
\end{tabular}

Regarding the "Cognitive high level thinking skills and status of achieving the objectives", the history teachers declared their opinions on the Cyprus and Cyprus Turkish History (CCTH) course in terms of research, investigation, use of information and technology, critical thinking, communicating, creative thinking, problem solving, and high level thinking skills that can fulfil the requirements and needs of the developing and changing 21 st century.

The qualitative data thus obtained reveals that the history teachers asserted that the CCTH course was unable to deliver the targeted gains and skills to students and the program was not as sufficient as had been expected. Sample statements regarding the achievement or nonachievement level of the course are given below:

"I would like to point out that the objectives and gains stated for CCTH course are too much. For example, it is not possible to gain so many skills and abilities such as research and investigation, using information and technology, critical thinking, communicating, creative thinking, solving problems, developing high level thinking skills to meet the needs and requirements of the 21 st century. It is not possible to gain all those skills or achieve the goals throughout this course. The content of this course must be more concise." (Teacher, 3).

"To be honest, I believe that it is not possible to achieve the objectives of the program, the achievement level of the high level objectives is low because they are not appropriate for the level of students. Students' level of readiness cannot be known." (Teacher, 5)

"Although using information and technology is one of the most important subjects of our present day and is amongst the objectives, there is no use of information and technology in the content of this course." (Teacher, 6)

"Within the content of the course on $\mathrm{CCTH}$, the targeted skills, for example, making students achieve the objectives or gain skills such as meeting the needs and requirements of the 21st century, is not possible. Amongst the reasons of this is that there is no learning environment in 
classrooms to achieve such an objective, and because of the time and financial restraints, only presentation of the course is possible and students mostly attempt to memorize the presented content. Besides this, I also would like to point out that, at this age through which the technology and science is prominent, we must deliver the skills of research and investigation to student; however, we are still insisting on memorizing things and why we do this in this way always generates a question in my mind." (Teacher, 1)

"If we want to train individuals who can cope with the developments and changes of the $21 \mathrm{st}$ century, it is necessary to consider the cultures, social structures, and customs and traditions of other countries. In my opinion, knowing about the values of other countries ensures easier establishment of communication with other societies. More importance must be given to daily events." (Teacher, 12)

"Objectives are taking part in the program; however, in practice, these objectives cannot be achieved by the students as the topics are in abstract form, and there are lots of subjects to be taught. The objectives of the program cannot be delivered to students to ensure sustainable behaviors or skills. Also, only limited information about the globalized world can be delivered to students." (Teacher, 5)

"As all the objectives of the course cannot be delivered to students, I would prefer not to include all these objectives in the course content. I believe that the objectives which are applicable must take place in the course objectives. (Teacher, 7)

The opinions of the teachers teaching the CCTH course reveal that the objectives related to high level cognitive thinking skills cannot be achieved effectively. In general, it is aimed to investigate the following issues related to course objectives: when the course is implemented efficiently, the achievements of students in terms of knowledge, skill and gains are assessed.

In the light of these findings, it could be suggested that the possibility of achieving the program or course objectives must be considered carefully when the teaching programs are designed and developed. The objectives that many no longer be appropriate or that cannot be achieved must not be included in the program.

In the second theme, which was based on "Thinking skills related to teaching history", the teachers stated their opinions on the objectives of $\mathrm{CCTH}$, including chronological thinking skills, historical thinking, analysis, interpretation, research based on exploring history, skills to perceive the political, cultural, social and economic events, and understanding the universal values in which the national values are particularly emphasized.

The qualitative data obtained from the teachers indicates that the objectives of the CCTH course taught to year 6-7-8-9-10 school groups have been achieved to a certain extent. In this regard, objectives related to thinking skills in history have also been achieved to some level. The statements of the teachers related to achieving the objectives of the history course are given below: "The CCTH course aims to develop students' thinking skills in analyzing and interpreting the important events taking place in Turkey and throughout the international platform. However, although achieving these objectives has been limited because of various reasons, I can claim that I am able to make my students achieve these objectives and teach these skills to my students. Because of the time restrictions due to the course hours, which is one of the most important negative aspects, any minimal teaching activities can be carried out in order to teach research skills, which are based on exploring history." (Teacher, 22)

"The CCTH course aims to make students learn both national and international history and culture; however, the national values are given more priority. The aim is to improve the 
students' skill related to analyzing the political relations of Turkey with other countries and changes in the globalized world. National values are the focal point of the course and universal values are also taught." (Teacher, 11)

"In this course, national values are the central aspect of the teaching goals and obtaining national unity with the values in Turkey is successfully achieved." (Teacher, 12)

"I believe that course content focusing on national, social, cultural and political values must be given more emphasis in the CCTH course." (Teacher, 22)

"For students studying in the final year of the secondary education, knowing about the contemporary history helps them to raise awareness about the present day and prepare for the future. In this respect, the CCTH course must be taught at all stages of the teaching programs and skills to carry out critical thinking about history must be provided to students, if we want to educate individuals who can cope with the requirements of the evolving era we live in." (Teacher, 14)

According to the teachers, whose opinions are given above, the course objectives in terms of students acquiring critical thinking skills about history throughout the CCTH course have been achieved to a certain extent; however, the level of achievement was lower than anticipated. In this respect, the history programs or courses must be redesigned to teach students skills related to how to analyze international developments in historical terms, and the information must be redesigned to a certain level whereby the students can successfully use and produce the information and knowledge wherever necessary.

In the light of these findings, it could be argued that the skills related to historical analysis, interpretation, analysis on national and international history, culture, economy and politics must be considered while developing the history teaching programs and courses.

\section{Results and Discussion}

The history teachers engaged in this research asserted in their statements that they were not well-informed or had not received in-service training regarding the objectives and content of the CCTH course and, therefore, they were unable to implement the program as required. So, the history teachers should take in-service training related to this course as well as seminars providing beneficial information about the teaching-learning process of this course. Moreover, they stated that designing a teacher's handbook about the implementation of this course would be highly beneficial.

On the other hand, within the scope and findings of this research, the teachers claimed in interviews that they did not understand the philosophy of this course and because of this, they were not satisfied with the objectives of the course. The teachers who analyzed course objectives and explored the details of the course stated that the content of the course in its present format is not helpful for teachers, does not provide guidance to teachers and, due to the lack of time, the targeted objectives cannot be achieved.

It was discovered that the objectives are not specifically in line with the course objectives, and activities and assessments cannot be conducted as required. The teachers claimed that the objectives of the course and the applications required to be implemented throughout the course are not in coherence. In line with the findings of this research, in their research, Şad and Karaova (2015) established that the teachers were unable to follow the requirements of the program throughout the implementation process. 
Furthermore, the teachers stated the program's objectives and goals should be more accurate. The teachers do not use the course book as the main teaching source because is lacks sufficient quality to attract the interest of students and the book was not written in coherence with the phasing principle. Moreover, the visual materials included in the book, such as photos, maps, drawings, tables, and paintings do not correspond with the text. The Cyprus and Cyprus Turkish History course, found that, in terms of the opinions of the teachers and students, the course book content was interesting for teachers, but the students did not have the same perspective. It stated that the teachers claimed that the texts and materials included in the book were in coherence; however, the opinions of the students were negative on this issue.

Another important finding of this research is that the infrastructure of the classrooms is not appropriate for the use of technological materials and, because of this, the technological materials required to be used within the scope of this course cannot be utilized. In fact, the teachers stated that there is no access to technological materials. Technological materials are believed to improve the quality of teaching and positively contribute to the motivation of students. The relevant literature also reveals that using technology improves the quality and is beneficial in history teaching (Demir \& Duruhan, 2015; Orakc1, 2012). In line with these findings, Öztürk (2012), in his research conducting interviews with students, found that enriching the content of the course by incorporating films and visual materials would be significantly more beneficial for students.

One of the fundamental objectives of the Cyprus and Cyprus Turkish History course is to make the students the focal point of the teaching process, taking the individual differences of students into consideration, making students think, prompting them to investigate, ask questions and to share opinions with others (MEB, 2016). However, amongst the findings of this research, it was found that the activities to engage students in critical thinking activities and other teaching-learning activities do not occur in the classroom studies. Thus, in line with the opinions of the history teachers and findings of the relevant research, the content of the CCTH course must be reviewed and redesigned. Furthermore, teachers should receive training that will make them more aware about all objectives of the recent curriculum. 


\section{References}

Akyuz, Y. (2014). Turk egitim tarihi M.O. 1000 - M.S. 2014. Ankara: Pegem Publishing.

Batdi, V. (2014). Ortaogretim matematik ogretim programi iceriginin rasch olcme modeli ve nvivo ile analizi. Electronic Turkish Studies, 9(11), 93-109.

Brown, J. D. (1989), 'Language program evaluation: A synthesis of existing possibilities'. In K. Johnson (Ed.), The second language curriculum. Cambridge: Cambridge University Press.

Demir, O., \& Duruhan, K. (2015). Ilkokul 2. sinıf Ingilizce dersi programi uygulamalarina iliskin ogretmen gorusleri. International Journal of New Trends in Arts, Sports \& Science Education, 4(3), 25 - 36.

Demirel, O. (1996). Genel ogretim yontemleri. Ankara: USEM Publications.

Demirel, O. (2006). Egitimde program gelistirme: Kuramdan uygulamaya. Ankara: Pegem Publishing.

Dogan, H. (1997). Egitimde program ve ogretim tasarimi. Ankara: Onder Press.

Erden, M. (1995). Icerik sentezleme stratejilerinin erisige etkisi. H. U Egitim Fakültesi Dergisi, $11,111-117$.

Erden, M. (1998). Egitimde program degerlendirme. Ankara: Ani Publishing.

Erturk, S. (2013). Egitimde program gelistirme. Ankara: Edge Akademi.

Fitzpatrick, J. L., Sanders, J. R., \& Worthen, B. R. (2004). Program evaluation: Alternative approaches and practical guidelines. New York: Pearson Education Inc.

Gibbs, G. R. (2002). Qualitative data analysis: explorations with NVivo. Buckingham: Open University Pres.

Hopkins, D. (1989). Evaluation for school development. Milton Keynes: Open University Press.

Kocoglu, E., \& Aydin, M. (2017). Alan uzmanlarina gore 2017 sosyal bilgiler programinin 2005 programi cercevesinde analizi. International Journal of Social Science Research, 6(1), 61-74.

Kose, E. (2011). 2005 Ilkogretim matematik programinin egitsel elestiri modeline gore degerlendirilmesi. Adnan Menderes Üniversitesi Eğitim Fakültesi, 2(2), 1-11.

Kucukahmet, L. (1995). Ogretim ilke ve yontemleri. Ankara: Gazi Buro Kitapevi.

Marsh, C. J., \& Willis, G. (2007). Curriculum: Alternative approaches, ongoing issues. (4th ed.). Upper Saddle River, NJ: Merrill Prentice Hall.

Milli Egitim ve Kultur Bakanligi (2016). Temel Egitim Kibris ve Kibris Turk Tarihi Dersi Ogretim Programi, KKTC Milli Egitim ve Kultur Bakanligi, Talim Terbiye Dairesi.

Miles, M. B., \& Huberman, A. M. (1994). Qualitative data analysis. London: Sage Publication.

Oliva, P. F. (1988) Developing the curriculum. Scott, Foresman and Company: Boston.

Orakci, S. (2012). Ilkogretim 7. siniflar icin uygulanan 2006 Ingilizce ogretim programinin ogretmen goruslerine gore degerlendirilmesi (Unpublished master thesis). Gazi University, Institute of Educational Sciences, Ankara. 
Richards, L. (2002). Using NVivo in qualitative research. Melbourne: QSR.

Sakaoglu, N. (2008). Ilkokul tarih programlari ve ders kitaplari, tarih ogretimi ders kitaplari. Istanbul: Tarih Vakfi Yurt Publications..

Saylor, J. G., Alexander, W. M., \& Lewis, A. J. (1981). Curriculum planning for better teaching and learning. New York: Holt, Rinehart and Winston.

Şad, S. N. \& Karaova, M. (2015). Ilkokul ikinci sinif Ingilizce dersi baglaminda dinleme becerisi ogretimi: Bir durum calismasi. Egitimde Nitel Arastirmalar Dergisi, 3(2), 66 95.

Tavsancil, E., \& Aslan, E. (2001). Sozel, yazili ve diger materyaller icin icerik analizi ve uygulama ornekleri. Istanbul: Epsilon Bookstore.

Tezcan, M. (1985). Egitim sosyolojisi. Ankara: Ankara Universitesi Press.

Tyler, R. W. (1975). Basic principles of curriculum and instruction. The University of Chicago Press: Chicago, IL.

Varis, F. (1988). Egitimde program gelistirme. Ankara: Ankara Universitesi Press.

Varis, F. (1997). Egitimde program gelistirme. Ankara: Alkim Publishing.

Wiles, J., \& Bondi, J. (1993). Curriculum development: A guide to practice. NY: McMillan Publishing Company.

Worthen, B. R. \& Sanders, J. R. (1973). Educational evaluation: Theory and practice. Belmont, Calif: Wadsworth.

\section{Biodata of the Corresponding Author}

İpek Danju works as an Assistant Professor at Near East University, Ataturk Faculty of Education. In February 2018, she was appointed to be Open, Common and Elective Courses (DOSD) Assistant Coordinator and Courses Commission Coordinatorship at Near East University. 